\title{
Walking the Past, Acting the Past? Peace March to Srebrenica Commemoration
}

\author{
Ana Ljubojević (D) \\ Centre for Southeast European Studies (CSEES), University of Graz, Austria \\ Email: ana.ljubojevic@uni-graz.at
}

\begin{abstract}
This article is based on an ethnographic study carried out during the Nezuk-Potočari Peace March in the framework of Srebrenica genocide commemoration. A more than 100-kilometer procession, attracting each year around 5,000 participants, represents the reverse route of the so-called Death March, the local population's way of escape from the town of Srebrenica in July 1995. Following theoretical insights from both memory studies and cultural geography, this article's aim is to analyze mnemonic practices commemorating the Srebrenica genocide in Bosnia and Herzegovina. Moreover, it explores the social processes through which such memory is produced, performed, and maintained. While applying participant observant methodology, I have engaged in conversation with residents and main actors taking part in the Peace March. Finally, the notion of collective memory is approached from the perspective of spatial mobility engagement of people visiting commemorative events and monuments dedicated to the 1990s war in Bosnia and Herzegovina.
\end{abstract}

Keywords: Southeastern Europe; collective memory; ethnography; cultural geography

On the first Sunday of July 2018, once we have managed to put all our camping equipment and a dog in the car, my colleagues and I leave Zagreb and head off for Tuzla in Bosnia and Herzegovina. Like most of the town's inhabitants, we have spent the evening watching the football World Cup quarterfinals between Russia and Croatia. Our host, who greets us after the long, nerve-wracking game won by Croatia, comments that he doesn't know how he survived it.

This familiar phrase, uttered by a sports fan, suddenly gives me chills, since I subconsciously associate it with the Nezuk to Potočari, Peace March. ${ }^{1}$ The march intends to pay respect to the victims of the Srebrenica genocide and we are about to embark on the route the next day. Widespread massacres in Srebrenica have come to emblemize the war in Bosnia and Herzegovina (BIH), when the Army of Republika Srpska, led by General Ratko Mladić and backed by the Army of Yugoslavia and various paramilitary units, took control of the town and killed more than 8,000 Bosniaks, mainly men and boys, in just a week.

Following theoretical insights from both memory studies and cultural geography, this article's aim is to analyze mnemonic practices commemorating the Srebrenica genocide in Bosnia and Herzegovina. My main hypothesis is that the Peace March, as a form of spatial mobility engagement of people visiting battlefield and massacre sites, monuments, and commemorative events, represents an act of unconscious reenactment.

First, I give an overview of the theoretical framework used in this research in which the relationship of space, place, and territory with individual and collective memory is discussed.

\footnotetext{
(C) The Author(s), 2021. Published by Cambridge University Press on behalf of the Association for the Study of Nationalities. This is an Open Access article, distributed under the terms of the Creative Commons Attribution licence (http://creativecommons.org/licenses/by/4.0/), which permits unrestricted re-use, distribution, and reproduction in any medium, provided the original work is properly cited.
} 
Furthermore, I provide some context regarding the aftermath of the Srebrenica genocide and the creation of a memorial initiative Peace March. Finally, the analysis of the Peace March as an act of reenactment is presented and followed by concluding remarks.

\section{Movement of Memory and Memory of Movement}

Two main theoretical aspects of relationship between memory and space are applied in this research: 1) the process of inscribing of memory into space, and 2) the role of memory in secular pilgrimages and reenactments.

\section{Geographies of Memory}

In order to demonstrate under which circumstances a place becomes the subject of cultural trauma and collective memory, ${ }^{2}$ I use conceptual tools of spatialization, localization, and territiorialization of memory (Fabri 2016). Notions of space ${ }^{3}$, locality and territory are confronted in order to delineate socio-spatial practices juxtaposed in places of memory. This research deals with a specific class of "memory places" - terrorscapes, described by Rob van der Laarse (2013) as places "where terror, political or state-perpetrated violence has happened or was prepared - seeking to understand both what happened as well as how the space-times of terror are collectively remembered or forgotten" (71). ${ }^{4}$

The process of spatializing memory connects space and time with social and mnemonic practices. It situates memory both in specific physical space and in determined moment in time (Fabri 2016; Giddens 1983). Moreover, in line with Edward Soja's definition of spatialization, the physical space, through social practice in time, develops new meanings (1990). Finally, the process of spatialization socially constructs both the discursive notions of space and of "imaginary geographies" and non-discursive ones (Shields 1992).

The localization of memory is understood mainly as "the organizational strategy which generates identity, involves sense of belonging [ ...] and serves as link between physical place and sense of the place" (Fabri 2016, 49). The localization thus creates symbolic meaning and interpretation of the space and pretty much coincides with what Lefebvre calls "representational spaces," or "space as directly lived through its associated images and symbols" (Lefebvre 1991, 39). Traumatic war events and "violence imposed on a place bears not only the implicit challenge to the identities associated with it, but also [ ...] provokes responses intimately related to a well-developed sense of place" (Povrzanović Frykman 2002, 69-70). Consequently, this research follows Casey's (1993) argument underlining the power of the place "to direct and stabilize us, to memorialize and identify us, to tell us who and what we are in terms of where we are (as well as where we are not)" (xv).

Finally, the territorialization of memory is a process of drawing boundaries and putting memory on the map. It also expresses the institutional dimension of creating memory, as well as "relations between institutional mechanisms and implementation of memory politics" (Fabri 2016). While the Peace March itself falls under the focus of spatialization and localization of memory, the official state-sponsored annual commemoration for the victims of Srebrenica genocide at Potočari Memorial Center is subject of the territorialization of memory.

\section{Memories of Movement}

When analyzing individual and group dynamics of the Peace March, this research extensively relies on and borrows analytical tools from reenactment and pilgrimage studies. Pilgrimage is usually defined as a religiously or spiritually motivated journey of one person or a group to a place regarded as sacred (Margry 2008). Clearly, this definition has been broadened over the years to encompass not only religious practices, but also phenomena deemed secular pilgrimages that may still have a sacral significance to the participants (Reader 2007). In this sense, traditional religion offers tools for expressing grief and setting up rituals of mourning (Lloyd 1998). 
In case of the Peace March, where grassroots practice and the official commemorative event carry strong performative component, Michael Billig's theoretical framework of "banal nationalism" (1995) seems particularly significant. Billig argues that national identity is predominantly produced and reproduced in a variety of social fields and cultural forms that is commemorations, sporting events, and national holidays. Hence, commemorative practices, from the Durkheimian point of view, operate as the nation's integrative force, and they also mean, symbolize, or express the conscience collective and feeling of togetherness (Durkheim 1995 [1912]). This performative character of contemporary identity formation processes (Fox \& Miller-Idriss 2008) draws attention to their dynamic character and the frequent drawing on symbolic repertoire from popular symbolic images, rituals, and sites. Olick and Robbins argue that the collective memory is processual: it is not a static category that we own, but a dynamic process in which members of the community are involved (Olick \& Robbins 1998). By participating in commemorations, an individual confirms his or her belonging to a "mnemonic community" (Zerubavel 2003). Moreover, the repetitiveness of such memorialization practice draws the lines of the community and reaffirms the group's collective identity (Olick \& Robbins 1998).

Similarly, reenactments try to tackle the past, to find authentic experience through performative action, while commemorating historical events and paying homage to ancestors. The outcome can be thought of as a form of affective history (Agnew 2007) in which an official historical narrative is transformed into intimate, individual experience through processes of "immersion, embodiment, heightened emotion, and empathy" (Agnew 2020, 22). Both pilgrimages and reenactments are entirely performative activities that look to the past and produce narratives shared by those participating in the experience (Taylor 2006). This performative character of contemporary identity creation is also produced and reproduced during the Peace March, and it is as well to be found in top-down initiatives like official commemorations.

Finally, the focus of pilgrimage literature stretched from the sacred site as the ultimate goal of the pilgrimage to include the journey towards a final destination. Thus, this research's perspective sees movement both as a performative action culminating with the official commemoration of the Srebrenica genocide, but also as an embodied action in which the physical co-presence and strenuous effort of the participants play an important role in the symbolical re-enactment of the horrors of war. Such reframing of pilgrimage cultures that is exploring "movement within movement $[\ldots]$ can provide opportunities to reflect upon, re-embody, sometimes even retrospectively transform, past journeys" (Coleman and Eade 2004, 18).

\section{The Context of Srebrenica and Peace March}

Wide-spread killings in the Bosnian town of Srebrenica stand as a symbol of the war in Bosnia and Herzegovina: "Its name has become synonymous with what is considered the worst atrocity in Europe after 1945" (Duijzings 2007, 141). Srebrenica, thus, "has come to represent the key through which the wars of the 1990s are understood" (Gordy 2013). A commemoration for the victims of Srebrenica has taken place in Potočari Memorial Center on July 11th each year since 2002, when the first such memorial event took place (Mulaj 2017).

The Srebrenica-Potočari Memorial Center and Cemetery for the Victims of the 1995 Genocide, as the memorial center and vast, almost seemingly endless flower-shaped cemetery are officially called, lies on the territory of Republika Srpska, the Bosnian Serb entity. The Office of the High Representative had played a crucial role in seconding supporting the demands from the victims' families by enabling the commemoration practice that enabled commemorative activities to take place on the spot where most of the women of Srebrenica last saw their sons and husbands, the battery factory in Potočari (Bougarel and Helms 2007; Nettelfield 2010; Wagner 2008, 2010; Pollack 2003; Simić 2009). In the part of Bosnia and Herzegovina where commemorations are dominated by an official discourse that privileges Serb experiences, such an occurrence, with Bosniaks 
re-establishing their presence in Srebrenica, to some extent represents in a certain way an "undoing" of the ethnic cleansing and genocide (Duijzings 2007).

The International Criminal Tribunal for the former Yugoslavia (ICTY) dealt with the Srebrenica massacre in twelve court cases - it is by far the most complex crime tried before The Hague tribunal. Furthermore, Srebrenica is the only crime committed during the wars of the 1990s for which there are convictions for genocide. The first ICTY judgment proving that the massacre in Srebrenica was an act of genocide - i.e. the Krstić case - represented a breakthrough in both the development of the international humanitarian law and in terms of political impact: it established "beyond any reasonable doubt that a crime of genocide was committed in Srebrenica" (ICTY 2001) against "a part of the Bosnian Muslim people as a national, ethnical, or religious group” (ICTY 2001). Victims' suffering was described in detail:

women, children and old people forced to climb into buses leaving for destinations unknown; men separated from their families, stripped of their belongings, men fleeing, men taken prisoner, men never to be seen again, men who would be found - but not always - dead, corpses piled up in mass graves; corpses with their hands tied or their eyes blind-folded frequently; dismembered corpses as well; unidentified corpses [ ...] corpses. (ICTY 2001)

The ICTY trial chambers stated as cause that the attacks were motivated by a desire for continuity of contiguous Serbian territory, because of Srebrenica's proximity to the Serbian border. The ICTY clearly did not want to downplay the severity of the crime and rejected the voices trying to depict men in Srebrenica as soldiers of the Army of Bosnia and Herzegovina (ARBIH). Instead, the tribunal stated that people from Srebrenica, "whether members of the 28th Division [of ARBIH] or not, [ ...] decided to flee through the woods towards Tuzla" (ICTY 2001). The judgment furthermore described the location of the mass executions, but also recalled the denial of the genocide and Bosniak victims by the Serbian sides. Namely, the Trial judgment underlined that in front of Pilica Dom, one of the mass executions sites, a memorial "in honor of the [ ...] Serbian heroes who died for the Serbian cause" (ICTY 2001) was erected after the war in present what is now Republika Srpska entity. On the other hand, there is not a single memorial plaque marking the location where almost 600 civilians were killed in July 1995 in a matter of days.

Thus, the main aim of the Peace March can be seen as a protest against denial of crime of genocide, and as an implicit call "for [the] faster arrest and prosecution of [the] persons responsible for [the] crimes committed." 5 Listed on the official list of the genocide commemoration events, the Peace March pays respect to the victims of Srebrenica genocide and recalls the heinous crimes committed by the army and police forces of Republika Srpska.

Taking place every year since 2005, this walking procession starts on July 8 th in the village of Nezuk (municipality of Sapna) in order to arrive, three days later, at Potočari Memorial Center (municipality of Srebrebnica), some 100 kilometers away. The itinerary, whose official slogan is "to freedom via route of death" (trasom smrti do slobode), follows the reverse journey of the so- called Death March from Srebrenica to liberated territories near Tuzla. Nowadays, the Peace March is led by a group of survivors of the escape journey that around 15,000 Bosniaks embarked on after fleeing Srebrenica safe area in July 1995 in order to reach territories under the command of the Army of BIH. ${ }^{6}$ Organized by a group of advocates, survivors, and relatives of the genocide victims, each year it attracts more than 5,000 participants from Bosnia and Herzegovina and abroad. Each stage of this three-day march is between 25 and 30 kilometers long, with one major climb to Udrč mountain (1,042 meters above sea level). The logistics of the march are impressive: it ranges from trucks providing transport of heavy bags and backpacks to army personnel mounting tents and sanitation stations, from media representatives recording and reporting live to medical services along the way, and last but not least, to countless volunteers providing vouchers, food, and information to registered participants. In addition, so-called history lessons (historijski čas) are typically conducted twice a day: a shorter one during the daily break and an evening one at the campsites. Daily lessons 
mainly involve testimonies directly related to the actual local geographical sites, such as, for example, an "old beech" tree where major ambush attack struck the fleeing population's column in 1995. The landscape and narrative thus combine to provide a form of "embodied" knowledge about the past events. In contrast, the evening lessons offer more artistic representations dealing with genocide and its aftermath. Performativity does not manifest only through ritual practice that a priori pertains to a commemoration, but it is an important component of the organized program as well. For instance, all the programmed interventions are staged, either on a distinct constructed stage (at the campsites) or, during the breaks along the route, with clear roles assigned to the performer and audience.

The 2018 program, for instance, always began with the live interpretation of Srebrenica Inferno, performed by the girls' choir from Potočari primary school, and followed by book readings by local authors. Such artistic responses to trauma, although aiming to explain the context of genocide and its aftermath, create boundaries between the affected population and the participants of the Peace March. At the end of the march, the participants have the opportunity to attend the commemoration followed by the funeral service for the "burial of identified remains of genocide victims, found in mass graves on locations where the march route passed by." 7

\section{Methodology}

This research is based mostly on the ethnographic study carried out during the Peace March in 2018. Even though I have embarked on the journey with three other colleagues from Zagreb (which actually gave us a reasonable amount of visibility as "the Croatian group"), I have walked separately for most of the march in order to engage more easily with the other participants. That proved indeed to be the case, as I have experienced the walking effort more intensively and was involved in conversation all the time. I have mainly talked to the participants of Bosnian origin (from Srebrenica and surroundings, but also from many parts of $\mathrm{BIH}^{8}$ and other places around the world ${ }^{9}$ ). There were also many foreign participants: an overwhelming majority from Turkey ${ }^{10}$ (whose arrival was organized in large tourist/pilgrim/scout's groups ${ }^{11}$ ), followed by those coming from Iran, while the participants from the Western Europe or the USA were mostly enrolled in educational programs (summer university, study visit, or the like). ${ }^{12}$

I have analyzed the rich additional content presented during the march: firstly, various messages of the local political exponents and organizational committee members delivered at the official opening ceremony. Moreover, after each walking stage history lessons were taught either by historians and intellectuals, ${ }^{13}$ mostly from the Podrinje region, ${ }^{14}$ and were followed by survivors' testimonies and school students' literary works dealing with the topic of Srebrenica genocide. Also, 1,500 "mountaineer booklets" explaining topoi mostly related to the 1995 genocide were distributed to the interested participants along the route. ${ }^{15}$

In addition to my field notes, I monitored the media reports in order to get the broader picture of the official policy of the main mnemonic agents staging the event itself. Finally, even though the official genocide commemoration in Potočari is not the main focus of the analysis of this research, some considerations regarding the territorialization of memory have dealt with the Potočari funeral service and are followed by the concluding remarks.

\section{Memory and Landscape - "Kilometers of Memory"17}

It is six o'clock in the morning and the taxi is driving us from Tuzla to Nezuk. Although it is the beginning of July the weather is grey and the rain does not promise an easy journey ahead of us. Our final destination, the village of Nezuk in Sapna municipality, is the last populated place before the invisible ${ }^{17}$ border between the two entities in Bosnia and Herzegovina: Federation of $\mathrm{BiH}$ and Republika Srpska. Invisible are also the traces of the war and the front line the driver is pointing to us while approaching the beginning of the thirteenth Peace March. 
To an outsider, the landscape where some of the worst crimes after the WWII were committed is not giving much of a context. With most of the houses reconstructed and spatial interventions such as memorial plaques and monuments present only in the populated areas, a notion of "guilty landscape" 18 comes to mind while observing the beautiful nature hiding the scars of the war landscape not only as mute witness to the atrocities of war that took place in and around it, but also as "accuser who confront collective humanity with what was done in its name" (Brants 2011) (Figure 1). ${ }^{19}$

This imagined guilt is also a starting point of the process of spatialization of memory (Soja 1990), or the engraving of memory and remembrance into physical space. However, in the course of the Peace March it is not only memory that conquers the space, but it is also a rather isolated opportunity for survivors and bereaved to make an "intervention" 20 in predominantly Bosnian Serb spaces of the Podrinje region. Thus, many participants attempt to grasp not only their reconstructed return/homecoming, but also an impressive three days walk in harsh weather conditions. $^{21}$

The landscape that almost 6,000 trekkers have traversed during the march is largely an "imaginary one," as the participants have not been driven to Eastern Bosnia because of the stunning nature, but because of the associations attached to the sites they have walked over (Lloyd 1998). Therefore, the landscape itself is placed within the wider context of memory of war, following both the narrative of the sacrifice and victimhood related to genocidal nature of crimes. Even though the victims of genocide were civilians and therefore could not act or fight against the massacre, they are all being named šehidi (martyrs) 22 as if they actively sacrificed themselves. This practice is also noticeable during the religious service where selected verses of Qur'an are being read. However, the

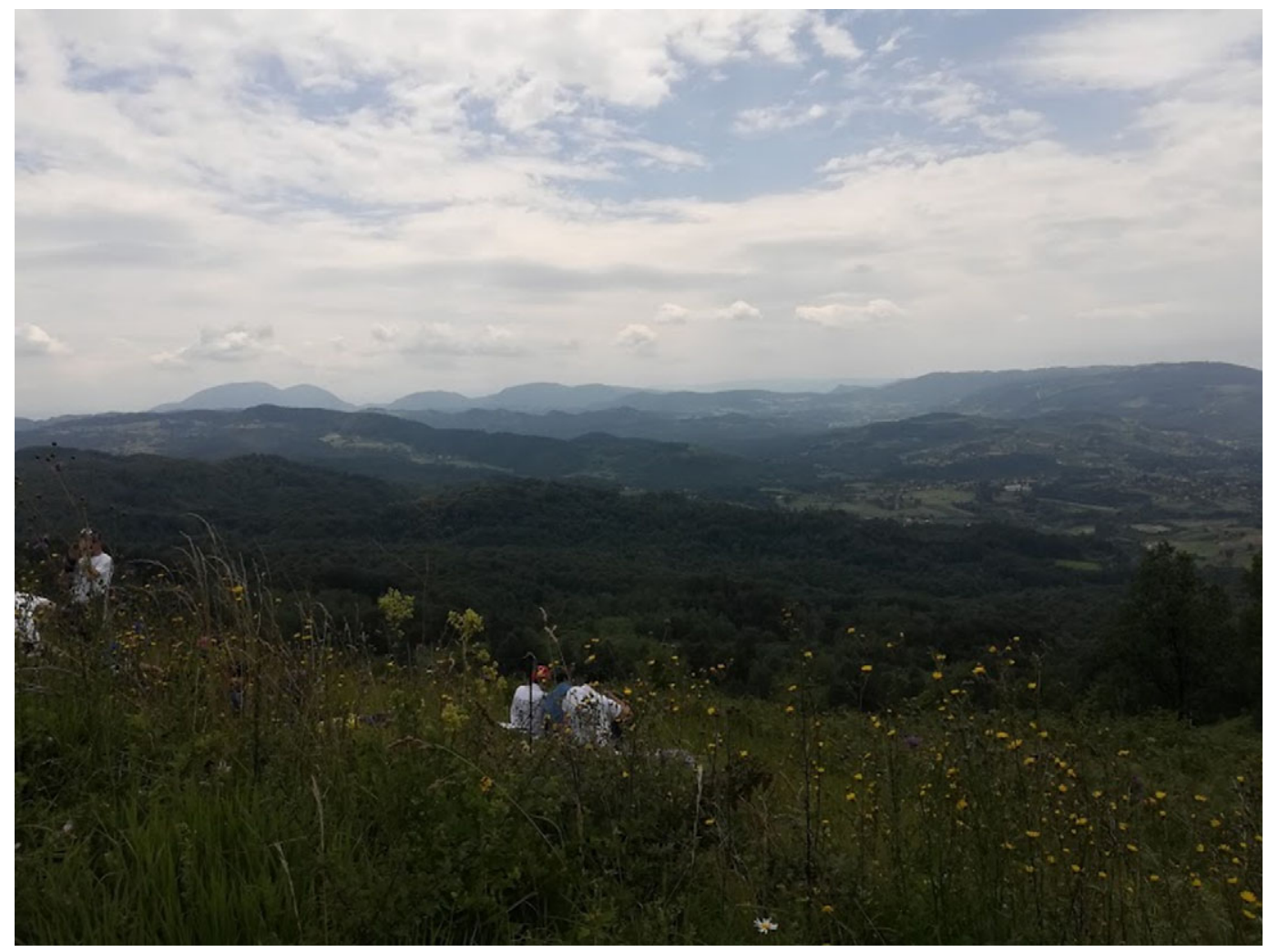

Figure 1. Landscape near Udrč mountain.

Source: The author. 
landscape is also related to the narrative of heroism of the Death March partakers who tried to escape attacks of the Army of Republika Srpska from Srebrenica to Tuzla. Indeed, the Peace March is one of the rare commemorative events in Srebrenica where the focus of attention is laid also on the members of the ARBIH 28th brigade ${ }^{23}$ who counted up to one third of the column and held a decisive role in reaching the rest of the ARBIH forces near Tuzla in the immediate aftermath of the genocide. ${ }^{24}$ Consequently, memory of the space was linked both to the presence of the dead and, especially for the 1995 Death March survivors - the presence of their past (Lloyd 1998). Such memory was enhanced and mediated/intervened with ad hoc signs describing the mass graves along the route ${ }^{25}$ : posters printed and glued to wooden supports were providing information about primary or secondary grave site, the number of the victims whose remains were found, the date of excavation, accompanied with a photograph of one personal object found on that spot (Figure 2).

There are no visual representations of the dead on those signs, but their presence is recalled, imagined, and felt everywhere, sometimes even pushed to extremes: as a Bosniak man in his sixties stated, "until 2009, on the first day [of the $\mathrm{march}$ ] we slept on a mass [grave] (prvi dan se spavalo na masovnoj). A year later it was discovered and exhumed."

There are many written and non-written rules controlling the movement of the March: the lead of the column is reserved for survivors and activists, there is no possibility to bypass the police control/escort in some Bosnian Serb villages, there is still a considerable number of mine fields forbidding the potential ideas of "shortcuts." For example, one participant who survived the 1995 Death March complained to me "as [he] cannot approach the house which was once held by the $\mathrm{ABIH}$, at the very beginning of the free territory. The Republika Srpska army ${ }^{26}$ is forbidding the access."

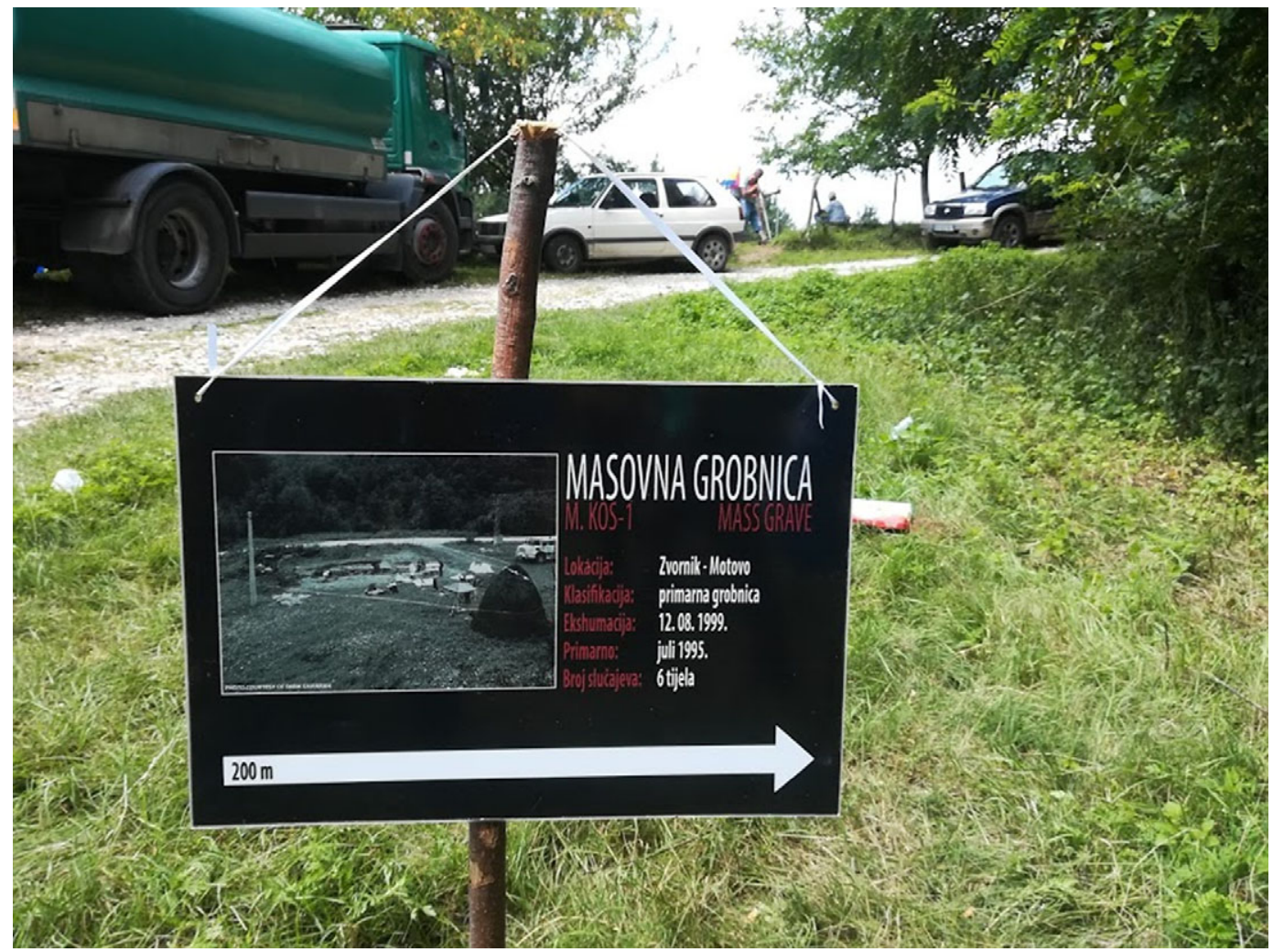

Figure 2. Mass grave sign.

Source: The author. 
Still, for one participant, a former refugee living now in Sweden, the very possibility of participating and walking again in the region of Eastern Bosnia represents "freedom - so that my children can study and live in peace." In addition, the Peace March was also an occasion to collect shattered memories: according to a Bosniak man in his early forties, "I was seventeen at the time [of the genocide], an acquaintance put me and my brother on the bus with women and children; later, his [brother's] bones were found in three different mass graves. I started to march in the past three years as I started to forget - my memories were overlapping and getting blurred, so I had to refresh them."

The walking procession and tracing of the space to some would be even repulsive if it was not for the cause of the march: “I have never been walking in the mountains. I can't really understand why would people climb on a hill without a cable car? But here, I came to pay respect to the victims and to the dead," remarked a Bosniak man in his 30s, from Prijedor and living in Austria.

One can of course assist the commemoration and funeral service at the Potočari Memorial Center and still pay respect to the victims of the genocide. Why is it then so important to retrace the suffering and visit this terrorscapes in their authentic and unaltered form? One argument is that the individual experience can form participants' personal interpretations of the site, which are later connected to the global/collective/cultural memory of the place. Therefore, the purely discursive notion of space and of "imaginary geographies" - in this case places of memory which are wellknown but not personally seen, and thus imagined - are embodied into concrete actions of individuals bonded together with a strong sense of common goal: it was the opinion of a woman in her 50s, of Bosnian origin but living abroad, that "one should live this experience [of Peace March] at least once in a lifetime. It's such a shame that all our people are not here with us to pay respect."

A group dynamic, which views pilgrimage as establishing a temporary, idealized order and community, was theorized by Victor Turner. According to Turner, individuals leave behind their relatively fixed state of life and are passing into a liminal or threshold phase and condition for which none of the rules and few of the experiences of their previous existence had prepare them (Turner 1969) in order to create an egalitarian bonding within so called communitas. One participant, a man from Visoko in his thirties, described a strong sense of the community and solidarity among marchers as "a typical fildžan viška $a^{27}$ (pending coffee) logic, the same one which cost us dearly during the war." For example, the participants helped each other to climb difficult passages, shared food, and gave away bandages and painkillers, but most importantly they had the impression of sharing the same cause and purpose of walking.

Nevertheless, critiques of the communitas theory have outlined the sometimes conflicting relationship between different groups of pilgrims. The Peace March was no exception. The amazing variety of participants' social, political, and class backgrounds was visible and sometimes underlined: many associations - NGOs, but also companies and factories - have provided their representatives with T-shirts revealing information of their geographical residence, groupness and sometimes political ideologies, as was the case with the Anti-Dayton ${ }^{28}$ group. In addition, the trekking equipment, and especially the lack of it during the heavy rain and difficult mountain climb, revealed not only the outdoors enthusiasts, but also the social class of many participants. However, the major conflicting element turned out to be the expression of religious sentiments.

The religious elements of all major professions of faith in $\mathrm{BIH}$ are frequently present in the public sphere, and not always in inclusionary manner, but are often addressing only the specific interest group. This was not the case with the Peace March, even though religion was very visible in many segments: the official commemoration was being called simply dženaza, ${ }^{29}$ the term for a Muslim funeral service, and prayers during the breaks were very common. However, the organizers repeatedly tried also to offer an alternative to religious components in the context of the universality of the march. The coordinators aimed to make the march as international and as inclusive as possible, and the over expression of the religious zeal was not well received among the Bosniak 
participants either: as one Bosniak man in his fifties stated, "Religion is being forced too much [previše se forsira], this [march] goes beyond it."

At the beginning of every history lesson, together with "the learning of Al-Fatiha," the opening chapter of the Koran, the organizers consciously offered alternatives to the usual religious practice with "a minute of silence or another appropriate way to pay respect to the innocent victims" 30 (Figure 3).

Similarly, when one group of scouts from Turkey started to call out loud Allähu akbar ${ }^{31}$ (at the outskirts of Bosnian Serb village) they were immediately silenced and reproached "because we are all going to dženaza and should remain silent." 32

\section{Memory and Place - "I Am Also from Srebrenica"}

Even though "national events such as wars [ ...] are experiences of shared grief that can help knit generation together" (Frow 2000, quoted in White and Frew 2013,2), the focus of this research is not on the dynamics of national identity, but rather on place identity from the experiential perspective, as well as on the challenges inscribed to it by different agents of memory. This article thus seeks to overcome nationally oriented memory studies focusing on construction of particular (group and/or individual) identities. In doing so, I follow Roger Brubaker's approach in opposing a taken-for-granted "groupist" constructivist paradigm (Brubaker 2006) and incorporating everyday contexts in which people "create their meanings of social context, and adjust their actions accordingly" (Koska 2008, 197). While the Peace March is without a doubt an extraordinary event, I was interest to trace patterns of everyday social ties and practices in such special circumstances. ${ }^{33}$

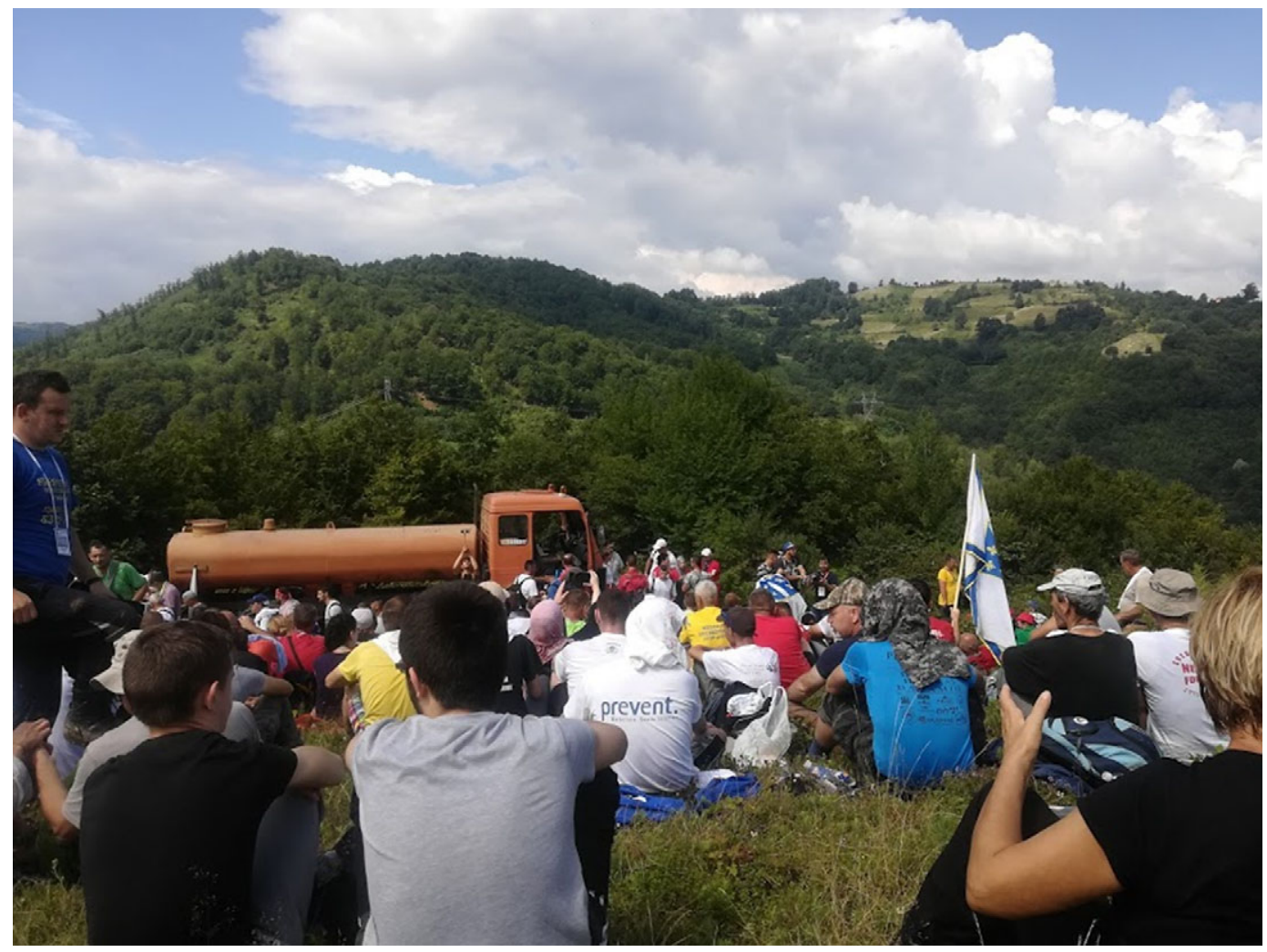

Figure 3. History lesson. Source: The author. 
In the case of the Peace March, the group dynamics was determined by shared experience and not shared national, ethnic or cultural identity. Thus, like in similar reenactments and pilgrimages, affective components assigned to a specific place of memory dictated social relations and practices.

The concept of place identity explores the meaning and significance of places for their inhabitants and users, and at the same time applies concepts of human-environment relationship to the studies of self-identity (Proshansky 1978, quoted in White and Frew 2013). In the context of pilgrimage and reenactment studies, Srebrenica and Potočari Cemorial Centre are the sacred place for Peace March, or, in other words, the outcome and cathartic location of the journey.

The creation of place identity has multiple layers and meanings and is most often recognized as an element of nationalization or even internationalization of memory. It is also an important element of both localization of memory and of cultural trauma processes. The reinvention of collective identity after traumatic event, typical for the cultural trauma claiming process, goes simultaneously with the process of attributing a particular identity to a place where, in the case of Srebrenica, the atrocities occurred. The attachment to the place and the sense of place was repeatedly outlined during the Peace March:

"The Peace March is an organized memorial procession commemorating the days of genocide. We follow the path of those Bosniaks from the safe haven Srebrenica who managed or did not manage to come through [to the free territory]. [ ...] This is a procession; this is a pilgrimage. We are going to a funeral (dženaza). Just remember how it was to those people in 1995. May that be the first thing on your mind." 34

When retracing the Death March, the outside participants, albeit only briefly occupying the physical space remembered by survivors, evoked a temporary sense of belonging to the place. The sense of belonging followed similar a pattern as in the case of group dynamics of communitas; however, the attachment to territory should not be understood as an issue of (ethno)nationality (Jansen 2005, quoted in Kockel, Nic Craith, and Frykman 2012), nor should it follow the sedentarist logic which presumes a naturalized link between people and place (Jansen and Löfving 2009). Belonging implies collectiveness: it answers to the question of "who we are" and what defines "us" and includes affective aspects in addition to the cognitive ones (Kovačević Bielicki 2016). In the case of such a liminal experience, the affective aspect indeed becomes predominant.

Moreover, a specific attachment to the traversed landscape was developed also with help of material objects, such as T-shirts printed with "I am also from Srebrenica," which were distributed to the marchers and intervened in the visual appearance of the column, as most of the people who received the T-shirt put it on during the march.

Similarly, walking the steps of those who escaped Srebrenica in July 1995 has given a specific "sense [ ...] of realization and of access to something beyond the normal levels and frameworks of everyday existence" (Reader and Walter 1993, 21) that is typical for pilgrimage. In fact, not only did some participants explicitly confirm to "take part to the Peace March as it was hajj ${ }^{35}$ " (a Bosniak man, 67), but the organizers also warned "that this [the march] is not an excursion - everyone who wishes to walk the march route can come before 7 July or after 12 July" (emphasis added). ${ }^{36}$

Furthermore, the organizers were constantly reminding participants that the Peace March was reversed, revisited, and to a certain extent defiant response to the real Death March - an opportunity to unite the living and the dead. Such claims were then repeated and reflected among participants, although complete embodiment was carefully avoided as a sign of respect towards those who perished. Even though the context of war, fear and hunger was something that could have been conceptualized rationally, emotionally it was very hard to understand: "are you sure you want to attend the Peace March? Did you bring some cans with you? And tents and pate ( $i$ šatore $i$ paštete)? It's easy like that - try doing it without anything, like they did it..." (Bosnian Croat from Tuzla, in his thirties).

In case of Podrinje, with Srebrenica standing out as a symbol of suffering and loss, place identity is closely related to the memory of the dead. The focus on the death has endorsed bereaved relatives, together with the group of survivors, as main carriers/actors of memory. Thus, the process of 
mourning integrated not only the victimhood and sacrifice of the men who died, but also the loss felt by women. Moreover, the nature of the Srebrenica genocide, whose victims were mainly men, changed dramatically demographic image of the town. Hence, women and their associations were left not only as key mnemonic actors, but as people with important political and social power as well. For the community of bereaved, the route crossed during the march, especially in the case of missing persons, represents the last way and trace which some of them might have taken or took before went missing.

The very last part of the march, when marble gravestones (nišani) of the Potočari Memorial Center and Cemetery were already visible through the woods, bore particular emotional charge (Figure 4). The column was silent, the survivors and victims' relatives marching in front, while bereaved women were "not with us anymore, but flying in front," as related by a Bosniak man in his early forties, describing his widowed sister's separation from their family group.

The arrival and the welcoming of the local population in Srebrenica evoked the mourning, albeit silent, of those who did not survive to come back: rows of people lined up next to the Memorial cemetery fence, crying or sobbing, touching unknown marchers as if they personified long lost loved ones, offering candies as a sign of gratitude.

\section{Memory and Territory - Making Boundaries}

The funeral service held every July 11th at the Potočari Memorial Center and Cemetary is the Peace March's concluding stop, which, together with the 1995 Death March, makes a full circle of exile and return. The arrival to Potočari valley, notwithstanding the huge crowd, was experienced individually as the participants walked in silence with their own thoughts, whereas the genocide commemoration assumed different rules and forms of group dynamics. Firstly, one is constantly confronted with numbers: number of victims, number of identified, number of missing, and number of buried. Moreover, there was a clear division between the bereaved and everybody else - if there was a sense of communitas throughout the march, social roles were repristinated once again during the commemoration practice. Finally, one singular form of exclusion was performed at the institutional level. For the last couple of years, the political speeches have not been delivered in front of the crowd, ${ }^{37}$ but inside the former battery factory among officials and invited guests. Even though there was live television streaming of the event on the state TV channel, people gathered at the cemetery could not follow what was happening only 200 meters away as there was no video or audio transmission. Such discrepancy paradoxically means that official discourse and politics of memory are only being unheard in situ, at the Potočari Memorial Center, during the particular timeframe of commemoration. However, as soon as one leaves the site, official speeches become again very visible via media, ready to interact, confront, or merge with individual and public memories.

The establishment of the memorial itself is the outcome of both material and non-material, as well as grassroots and top-down interventions. First of all, the complex occupies physical territory in Republika Srpska, but at the same time stands out from the RS politics of memory in terms of narrative and visible material legacy of the massacre. Moreover, the power relations of both domestic and international factors are expressed through territorial jurisdiction ${ }^{38}$ and finally, boundaries are created when implementing politics of memory. The location of the memorial center is a product of intensive struggle and efforts of the victims' families, for whom it "has served important psychological rather than political needs" (Duijzings 2007,153) in an attempt to find closure.

Throughout Bosnia and Herzegovina, memory practices concerning the "others," i.e. those not belonging to ethnic majority, have been reduced to "low-key commemorations and burials of identified victims recovered from mass graves" making thus "the return of the dead [ ... ] a symbolic return of those who survived" (Halilovich 2011, 44). Sometimes, there is an explicit ban on commemorative objects in certain Bosnian and Herzegovinian municipalities. For example, this 


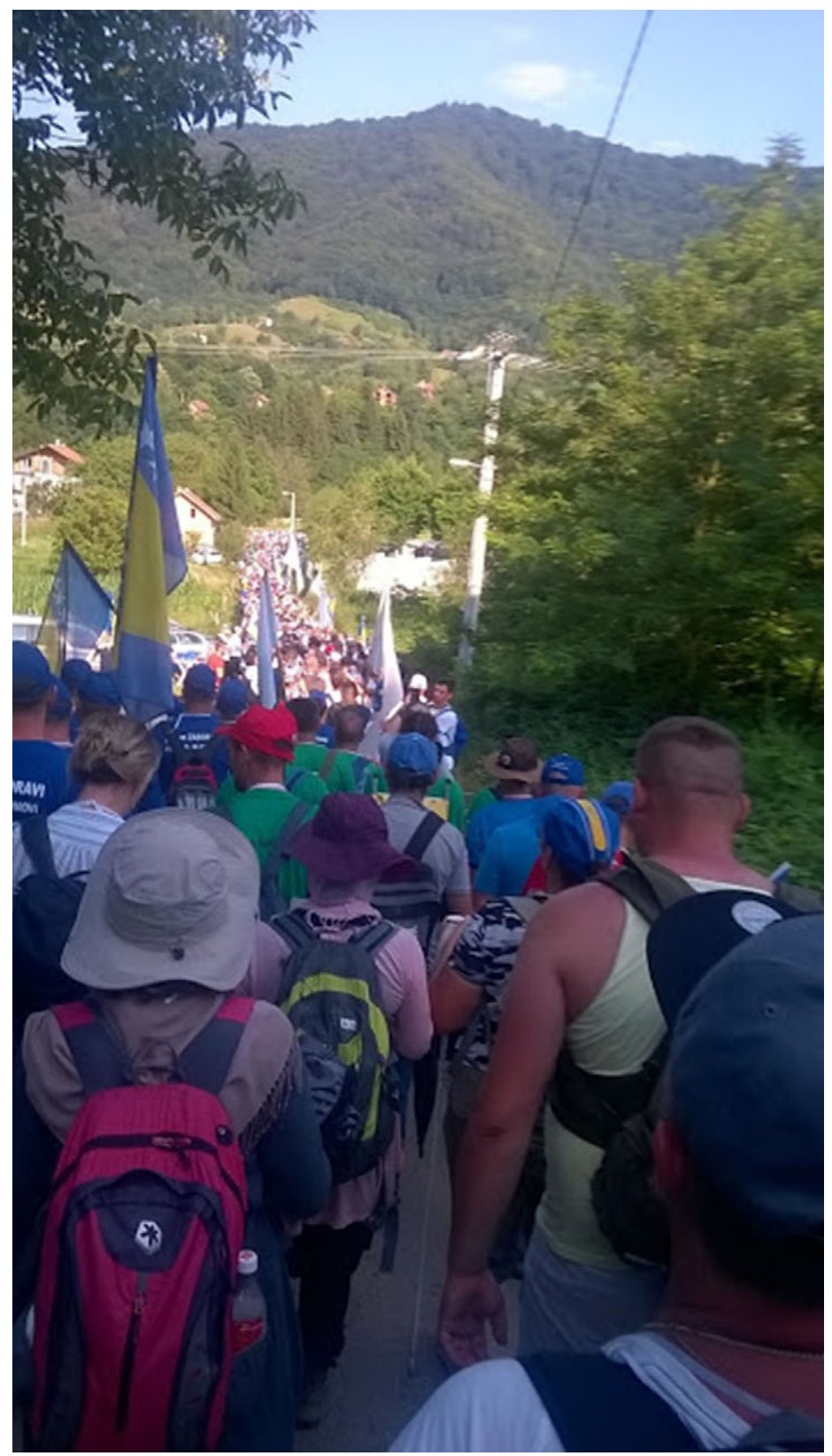

Figure 4. Arrival to Potočari.

Source: The author.

was for a long time the case of the Omarska camp near Prijedor, where many thousands of individuals were victims of crimes committed by Bosnian Serb forces in a widespread and systematic manner in $1992 .{ }^{39}$ Consequently, alternative grassroots memorial practices were developed with the so-called White Ribbons Day ${ }^{40}$ having the major visibility.

Out of more than 104,000 war victims in Bosnia and Herzegovina, 40 percent were civilians, ${ }^{41}$ a fact which could put the numbers of Srebrenica victims in a different perspective. However, with the commemoration of Srebrenica genocide, the internationalization and institutionalization process 
enacted a different type of politics of memory: just as the images of Auschwitz and Anne Frank tend to subsume all evocations of the Holocaust (White and Frew 2013), Srebrenica occupies a special place on the memory map of $\mathrm{BIH}$. Moreover, thanks to the close involvement of the international community, Potočari commemoration has "moved to the centre of the official commemoration of the war in Bosnia" (Duijzings 2007, 160). Finally, generous financial support and mediated attention have turned the Srebrenica commemorations "into acts of remembrance meant for international consumption" (Duijzings 2007, 160). I have myself thought for a longtime of the role I was having during the march, both as an insider and outsider. Even though I was sharing the cultural codes and language with the local community, my positioning was also related not only to my origin and current residence, but to my social role of researcher as well. Not once have we heard appeals from the participants to spread the story of Srebrenica outside of the BIH borders. Whether it could count as some sort of commodity exchanged for an authentic experience, in the framework of international consumption, I am reluctant to answer straightforwardly. But the story has been told.

\section{Conclusion}

The analysis of the Nezuk-Potočari Peace March has described the processes of spatialization, localization, and territorialization of memory from the perspective of pilgrimage and reenactment studies. While studying movement and embodiment of memory through engagement with physical space and place identity, this research also tried to grasp socio-political and religious meaning associated with the march. Moreover, the rationale for a bottom-up approach to collective memory came from an aspiration to bridge the existing normative gap: even though the memory studies theory underlined attempts to construct a common cultural identity, i.e. "presuppose a [ ... ] desire for cultural homogeneity, consistency, and predictability" (Kansteiner 2006, 23), the practice reveals a different state of affairs: contested memories, embracing different interpretations of the past that confront one another (Misztal 2003), produce divergent vectors of memory even within the same social group.

Although the Peace March follows the route of the 1995 Death March, where the soldiers of the Army of Bosnia and Herzegovina counted for one third, it is symbolically closely related to another war event: the genocide in Srebrenica. Thus, the aim of the journey - its sacral significance - is the annual commemoration in Potočari (including collective prayer and funeral service).

The Peace March as arena of memory included a range of diverse mnemonic actors, but also incorporated a strong emotional investment and feeling of authenticity of remembrance. However, this embodied experience towards symbolical quest of physical space and territory is not premediated to represent a reenactment per se nor it is described as such by the participants of the march. Nevertheless, I argue that the process of "touch[ing] the past [and discovering] authentic experience by re-enacting history" (Baraniecka-Olszewska 2018, 127) is the outcome and consequence of the Peace March. The main reason for such an unconscious reenactment is a combination of its topic, i.e., a journey to genocide commemoration, and presence of living testimonies taking part in the march. The bodies of the living and the dead are indeed symbolically bound together during the march due to the communicative dimension of the collective memory of Bosnian war, through testimonies and active engagement with the space and place. However, even though the Peace March retraces the path of the Death March, yet in reverse order and in completely opposed conditions, it is precisely through differences with the original march that the present-day journey facilitates the flow of memory.

Acknowledgements. The author would like to thank especially a wonderful group of six participants of the Peace March whose identities cannot be disclosed in order to respect the anonymity of the research.

Disclosures. None. 
Financial Support. The writing of this article was made possible through funding from the PIASt and Marie SkłodowskaCurie COFUND Action under the EURIAS Fellowship Programme, FP7 programme, grant agreement no 609400 and European Union's Horizon 2020 research and innovation programme under the Marie Skłodowska-Curie grant agreement No 795374.

\section{Appendix. List of informants quoted in the text}

\begin{tabular}{lllll}
\hline Ethnicity & Sex & Age & Date & Place \\
\hline Bosniak & M & 60 s & $9 / 7 / 2018$ & Peace March \\
\hline Bosniak & M & 50 s & $8 / 7 / 2018$ & Peace March \\
\hline Bosniak & M & 60 s & $8 / 7 / 2018$ & Peace March \\
\hline Bosniak & M & 40 s & $9 / 7 / 2018$ & Peace March \\
\hline Bosniak & M & 30 s & $8 / 7 / 2018$ & Peace March \\
\hline Bosniak & F & 50 s & $8 / 7 / 2018$ & Peace March \\
\hline Bosniak & M & 30 s & $10 / 7 / 2018$ & Peace March \\
\hline Bosniak & M & 50 s & $9 / 7 / 2018$ & Peace March \\
\hline Bosniak & M & 67 & $9 / 7 / 2018$ & Peace March \\
\hline Croat & M & $30 s$ & $7 / 7 / 2018$ & Tuzla \\
\hline Bosniak & M & $40 s$ & $10 / 7 / 2018$ & Peace March \\
\hline
\end{tabular}

\section{Notes}

1 When referring to the Peace march I will either use the its official name (Peace march) or shorten it to march. Due to its multiple meanings I have preferred not to define it as a procession or journey or pilgrimage.

2 A place is understood as concrete area in space which carries symbolic and affective charge and which manifests through individual and collective experiences and aspirations (Souto and Benedetti 2011). The notion of cultural trauma is used in accordance with Alexander's definition as an emotional, institutional, and symbolic reparation and reconstitution occurring when a traumatic event causes tears in social fabric and collective identity of a group (2004). Trauma claiming requires is, by definition, a process that generates production of memory. Like cultural trauma, memory can be also considered as a social construct (Halbwachs 1992), bound to the relationship between groups and individuals (Olick 1999).

3 I understand the space not only as a physical place, but also as a space of memory and imaginary sphere, relating mainly to the past or to an imaginable future.

4 From the website of Terrorscapes project: http://www.terrorscapes.org/about-us.html. (Accessed June 15, 2020.)

5 Information retrieved from the official website: www.marsmira.org/bs/marsmira.php\# (Accessed August 28, 2020).

6 Detailed information about the Srebrenica genocide can be found in Krstić judgment, retrieved from: www.icty.org/case/krstic/4. (Accessed August 29, 2020.)

7 Information retrieved from the official website: www.marsmira.org/bs/marsmira.php\# (Accessed November 28, 2018). 
8 Even though the ethnic belonging was not the focus of this research, it has to be outlined that the vast majority of the participants from BIH were Bosniaks living in the Federation of BIH entity.

9 Participants from diaspora were especially numerous. According to the UNHCR data 2.2 million people left Bosnia and Herzegovina during the 1992-95 war, while a total of 1,025,011 have now returned. See http://www.balkaninsight.com/en/article/bosnians-home coming-marred-by-post-war-tensions-and-poverty-02-21-2018.

10 According to the 2017 estimates of the organizational board, more than 1,400 Turkish participants joined the Peace March. See https://www.klix.ba/vijesti/bih/pripreme-za-mars-miraambasade-pomazu-deminiranje-terena/180223017.

11 This argument will be developed more in detail in the analytical part of the article.

12 Such groups have organized conversations with the local participants and survivors, either directly in English or with the help of local translators (and cultural mediators).

13 Sometimes, the credibility of their claims and historical narratives was questionable to say the least as they entered the domain of conspiracy theories. For example, one lecture discussed in detail "10 genocides" committed against Bosniaks in the course of history. Such interpretations were related more to a broader history of BIH and not to the Srebrenica genocide.

14 Region around Drina river. The notion is purely geographical and does not represent any administrative unit.

15 The booklet was published by the Sarajevo Mountaineer's Club "Fasto."

16 Peace March booklet.

17 Even though there are no border crossing controls, and the police is operating on the state level and wearing the same uniforms, it is very easy to understand in whose territory you are: the flags are exposed in front of every institution (the Republika Srpska has its own entity flag in addition to the state one, whereas in the Federation only BIH flags are hanged), the Cyrillic script is used only in RS (except for the double script signs which are present on institutions and roads under the state jurisdiction) and finally, religious objects and buildings represent a helpful indicator as well.

18 Term coined in the 1970s by the Dutch artist Armando in relation to the beautiful nature around WWII transit camp Amersfoort that had witnessed horrible war crimes. He integrated photographs of landscapes and historical events into his drawings.

19 all photographs were taken by the author between 8 and 10 July 11, along the course of the Peace March.

20 The concept of intervention was described by Nettelfield and Wagner (2014) as an act aiming to "interrupt and alter; to repair and restore; to reconstitute social relations in the aftermath of violence."

21 The 2018 march witnessed some of the worst July rains in recent years, making especially difficult the climb on mountain Udrč on the second day of the march. Because of the numerous medical interventions, the organizers decided to reuse the old route during the third day of the march, and not the recently demined one following the original Death march path. However, the weather conditions are always challenging as the temperatures are easily reaching over 30 Celsius in that period of the year.

22 šehid, a religious term in Islam - literally meaning "witness," metaphorically "martyr" - is used to designate fallen soldiers from the ARBIH units.

23 For example, one of the main speakers at the opening ceremony was the Minister for Issues of The Veterans and Disabled Veterans of the Defensive-Liberation War.

24 A detailed analysis of the Bosniak and Serbian narratives related to the war events in Srebrenica and subsequent commemoration practices can be found in Duijzings (2007).

25 The main execution sites (many of which were schools, farms, or warehouses) are mostly kept "in amnesia" and abandonment: only one memorial plaque exists in Nova Kasaba, whereas the absence of any sign on the others reflect the official politics of denial in Republika Srpska. 
26 Since 2006, the armed forces of BIH have functioned on the state level and the two entity armies ceased to exist. The participant was referring to the soldier (who was probably a Bosnian Serb) preventing him from making any deviation from the Peace March agreed track.

27 A metaphor for hospitality - one extra fildzan, i.e. coffee cup, is prepared because you never know if someone is going to pass by and visit you. My own experience during the march can only confirm this mindset, as I was invited to a family lunch by a group of co-walkers.

28 Movement aiming to restoration of the 1992 constitution in BIH, strongly opposing the 1995 Dayton Peace Agreement which established the current political structure in the country.

29 Reference to the July 11 th commemoration in Potočari.

30 The author's recordings of Peace March history lessons.

31 A common Muslim expression meaning "God is greater," ultimately often associated with Islamic extremism.

32 Official communication of the organizers, recorded by the author.

33 For example, what does the ritual of drinking coffee look like during the Peace March, how are some very personal practices such as praying performed, etc.

34 Official communication of the organizers, recorded by the author.

35 Annual Islamic pilgrimage to Mecca.

36 Official communication of the organizers, recorded by the author.

37 Victims' associations asked in 2012 not to have political speeches in Srebrenica, expressing their revolt because showing in Srebrenica became "collection of cheap political points".

38 The Memorial Centre is under the state jurisdiction of BIH.

39 Only in 2019, two commemorative plaques were put on so called "White House" (Bijela kuća) at the former camp site: https://www.dw.com/hr/logor-omarska-i-putuju\%C4\%87a-spomen-plo $\% \mathrm{C} 4 \% 8 \mathrm{Da} / \mathrm{a}-49919135$ (Accessed March 13, 2021.)

40 In May 1992, the non-Serb population had to mark their houses with white sheets and wear white ribbons around their sleeves in order to be "recognized."

41 https://balkaninsight.com/2007/06/19/justice-report-bosnia-s-book-of-the-dead/ (Accessed January 13, 2019.)

\section{Bibliography}

Agnew, Vanessa. 2007. “History's affective turn: Historical re-enactment and its work in the present." Rethinking History 11 (3): 299-312.

Agnew, Vanessa. 2020. “Refugee Routes: Connecting the Displaced and the Emplaced.” In Refugee Routes: Telling, Looking, Protesting, Redressing, edited by Vanessa Agnew, Kader Konuk, and Jane O. Newman, 17-29. Bielefeld: transcript Verlag.

Alexander, Jeffrey C., Ron. Eyerman, Bernard Giesen, Neil J. Smelser, and Piotr Sztompkaeds, eds. 2004. Cultural Trauma and Collective Identity. Berkeley: University of California Press.

Baraniecka-Olszewska, Kamila. 2018. “Sanctified Past: the Pilgrimages of Polish Re-enactors to World War II Battlefields.” In Military Pilgrimage and Battlefield Tourism: Commemorating the Dead, edited by J. Eade and M. Katic, 125-147. London: Routledge.

Billig, Michael. 1995. Banal Nationalism. Newbury Park, CA: Sage.

Bougarel, Xavier, and Elissa Helms, eds. 2007. The New Bosnian Mosaic: Identities, Memories and Moral Claims in a Post-War Society. Aldershot: Ashgate.

Brants, Chrisje. 2011. "Guilty Landscapes: Collective Guilt and International Criminal Law." In Cosmopolitan Justice and its Discontents, edited by Cecilia Bailliet and Katja F. Aas, 53-68. London: Routledge.

Brubaker, Rogers. 2006. Nationalist Politics and Everyday Ethnicity in a Transilvanian Town. Princeton: Princeton University Press.

Casey, Edward. S. 1993. Getting Back into Place. Toward a Renewed Understanding of the Place-World. Indianapolis: Indiana University Press.

Coleman, Simon, and John Eade. 2004. Reframing Pilgrimage: Cultures in Motion. London: Routledge.

Duijzings, Ger. 2007. "Commemorating Srebrenica: Histories of Violence and the Politics of Memory in Eastern Bosnia." In The New Bosnian Mosaic: Identities, Memories and Moral Claims in a Post-War Society, edited by X. Bougarel and E. Helms, 141-66. Aldershot: Ashgate.

Durkheim, Emile. 1995 [1912]. The elementary forms of religious life. New York, NY: The Free Press. 
Fabri, Silvina. M. 2016. Procesos socioespaciales y prácticas memoriales: Espacialización, Lugarización y territorialización en la recuperación del ex centro clandestino de detención "Mansión Seré." PhD Diss., University of Buenos Aires, Argentina.

Fox, Jon E., \& Miller-Idriss, Cynthia. 2008. "Everyday nationhood." Ethnicities, 8 (4), 536-563.

Frow, John. 2000. "In the Penal Colony." Journal of Australian Studies 24 (64): 1-13.

Giddens, Anthony. 1983. "Comments on the Theory of Structuration." Journal for the Theory of Social Behavior 13 (1): 75-80.

Gordy, Eric. 2013. Guilt, Responsibility, and Denial. The Past at Stake in Post-Miloševic Serbia. University Park, PA: University of Pennsylvania Press.

Halbwachs, Maurice. 1992. On Collective Memory. University of Chicago Press.

Halilovich, Hariz. 2011. "Beyond the Sadness: Memories and Homecomings among Survivors of 'Ethnic Cleansing' in a Bosnian Village.” Memory Studies 4 (1): 42-52.

ICTY. 2001. Radislav Krstić becomes the First Person to be Convicted of Genocide at the ICTY and is Sentenced to 46 Years Imprisonment. The Hague http://www.icty.org/sid/7964. (Accessed March 15, 2020.)

Jansen, Stef. 2005. "National Numbers in Context: Maps and Stats in Representations of the Post-Yugoslav Wars." Identities, 12 (1): 45-68.

Jansen, Stef., and Staffan. Lofving. 2009. "Introduction: Towards an Anthropology of Violence, Hope and the Movement of People." In Struggles for Home: Violence, Hope and the Movement of People, edited by Stef Jansen and Staffan Lofving. New York: Berghahn Books.

Kansteiner, Wulf. 2006. In Pursuit of German Memory: History, Television, and Politics after Auschwitz. Athens: Ohio University Press.

Koska, Viktor. 2008. "Return and Reintegration of Minority Refugees. The Complexity of the Serbian Returnees Experiences in the Town of Glina." Croatian Political Science Review 45 (5): 191-217.

Kovačević Bielicki, Dragana. 2016. "Neither on the earth, nor in the skies". Negotiations of (non)belonging among former Yugoslav refugees in Norway. PhD Diss., University of Oslo.

Lefebvre, Henri. 1991. The Production of Space. Oxford: Blackwell Publishing.

Lloyd, David. 1998. Battlefield Tourism: Pilgrimage and the Commemoration of the Great War in Britain, Australia and Canada, 1919-1939. London: Bloomsbury.

Margry, Peter. J., ed. 2008. Shrines and Pilgrimage in the Modern World: New Itineraries into the Sacred. Amsterdam: Amsterdam University Press.

Misztal, Barbara. 2003. Theories of Social Remembering. Theorizing Society Series. Maidenhead: Open University Press.

Mulaj, Klejda. 2017. "Genocide and the Ending of War: Meaning, Remembrance and Denial in Srebrenica, Bosnia." Crime, Law, and Social Change 68 (1): 123-143.

Nettelfield, Lara J. 2010. Courting Democracy in Bosnia and Herzegovina: The Hague Tribunal's Impact in a Postwar State. New York: Cambridge University Press.

Nettelfield, Lara, and Sarah Wagner. 2014. Srebrenica in the Aftermath of Genocide. Cambridge: Cambridge University Press.

Olick, Jeffrey. K. 1999. “Collective Memory: The Two Cultures.” Sociological Theory 17 (3): 333-348.

Olick, Jeffrey K., \& Joyce Robbins. 1998. "Social Memory Studies: From 'Collective Memory' to the Historical Sociology of Mnemonic Practices." Annual Review of Sociology 24: 105-140.

Pollack, Craig. 2003. "Intentions of Burial: Mourning, Politics, and Memorials Following the Massacre at Srebrenica." Death Studies 27 (2): 125-142

Povrzanović Frykman, Maja. 2002. "Violence and the Re-discovery of Place.” Ethnologia Europaea 32 (2): 69-88.

Proshansky, Harold. M. 1978. "The City and Self-Identity.” Environment and Behavior 10 (2): 147-169.

Reader, Ian. 2007. "Pilgrimage growth in the modern world: Meanings and implications." Religion 37: 210-29.

Reader, Ian., and Tony. Walter, eds. 1993. Pilgrimage in Popular Culture. Basingstoke: The Macmillan Press.

Shields, Rob. 1992. Places on the margin: Alternative geographies of modernity. London: Routledge.

Simić, Olivera. 2009. "Remembering, Visiting and Placing the Dead: Law, Authority and Genocide in Srebrenica." Law Text Culture 13 (1): 273-311.

Soja, Edward, ed. 1990. Postmodern Geographies: the Reassertion of Space in Critical Social Theory. London: Verso.

Souto, Patricia, and Alejandro Benedetti. 2011. "Pensando el concepto de lugar desde la geografía." In Territorio, lugar, paisaje. Prácticas y conceptos básicos en geografía, edited by Patricia Souto et al., 83-128. Buenos Aires: EDFYL, Universidad de Buenos Aires.

Taylor, Michael. 2006. Rationality and the Ideology of Disconnection. Cambridge: Cambridge University Press.

Turner, Victor. 1969. "Liminality and Communitas." In The Ritual Process: Structure and Anti-Structure, edited by Victor Turner, 94-130. Chicago: Aldine Publishing.

Kockel, Ullrich, Mairead Nic Craith, and Jonas Frykman. 2012. A Companion to the Anthropology of Europe. Malden, MA: John Wiley \& Sons

van der Laarse, R. 2013. "Beyond Auschwitz. Europe's Terrorscapes in the Age of Postmemory." In Memory and Postwar Memorials: Confronting the Violence of the Past, edited by Silberman, M. and F. Vatan, 71-92. New York: Pagrave Macmillan.

Wagner, Sarah. 2010.“Tabulating Loss, Entombing Memory: The Srebrenica-Potočari Memorial Centre.” In Memory, Mourning, Landscape, edited by Elizabeth Anderson, Avril Maddrell, Kate McLoughlin and Alana Vincent, 61-78. Amsterdam: Rodopi. 


\section{Ana Ljubojević}

Wagner, Sarah E. 2008. To Know Where He Lies: DNA Technology and the Search for Srebrenica's Missing. Berkeley: California University Press.

White, Leanne, and Elspeth Frew, eds. 2013. Dark Tourism and Place Identity: Managing and Interpreting dark places. London: Routledge

Zerubavel, E. 2003. "Calenders and history: A comparative study of the social organization of national memory". In Continuities, conflicts and transformations in national retrospection, edited by J. K. Olick, 315- 337. Durham, NC: Duke University Press.

Cite this article: Ljubojević, A. 2022. Walking the Past, Acting the Past? Peace March to Srebrenica Commemoration. Nationalities Papers 50: 1125-1142, doi:10.1017/nps.2021.30 